\title{
Neonates colonized with pathogenic bacteria in the airways have a low-grade systemic
} inflammation

Rahman Fink, Nadia; Chawes, Bo Lund; Thorsen, Jonathan; Stokholm, Jakob; Krogfelt, Karen ; Schjørring, Susanne; Kragh, Marie; Bønnelykke, Klaus; Brix, Susanne; Bisgaard, Hans

\section{Published in:}

Allergy

Link to article, DOI:

10.1111/all.13461

Publication date:

2018

Document Version

Peer reviewed version

Link back to DTU Orbit

Citation (APA):

Rahman Fink, N., Chawes, B. L., Thorsen, J., Stokholm, J., Krogfelt, K., Schjørring, S., Kragh, M., Bønnelykke, K., Brix, S., \& Bisgaard, H. (2018). Neonates colonized with pathogenic bacteria in the airways have a low-grade systemic inflammation. Allergy, 73(11), 2150-2159. https://doi.org/10.1111/all.13461

\section{General rights}

Copyright and moral rights for the publications made accessible in the public portal are retained by the authors and/or other copyright owners and it is a condition of accessing publications that users recognise and abide by the legal requirements associated with these rights.

- Users may download and print one copy of any publication from the public portal for the purpose of private study or research.

- You may not further distribute the material or use it for any profit-making activity or commercial gain

- You may freely distribute the URL identifying the publication in the public portal 
PROF. HANS BISGAARD (Orcid ID : 0000-0003-4131-7592)

Article type : Original Article: Experimental Allergy and Immunology

Handling AE: Liam O'Mahony

Neonates colonized with pathogenic bacteria in the airways have a low-

\section{grade systemic inflammation}

Authors: Nadia Rahman Fink, MD${ }^{1}$; Bo Lund Chawes, MD, PhD, $\mathrm{DMSc}^{1}$; Jonathan Thorsen, $\mathrm{MD}^{1}$; Jakob Stokholm, MD, $\mathrm{PhD}^{1}$; Karen Krogfelt MSc, $\mathrm{PhD}^{3}$; Susanne Schjørring, MSc, $\mathrm{PhD}^{3}$; Marie Kragh, MSc, PhD², Klaus Bønnelykke, MD, PhD ${ }^{1}$; Susanne Brix, MSc, PhD²; Hans Bisgaard, MD, $\mathrm{DMSc}^{1}$.

\section{Affiliation:}

1) COPSAC, Copenhagen Prospective Studies on Asthma in Childhood, Herlev and Gentofte Hospital, University of Copenhagen, Copenhagen, Denmark.

2) Disease Systems Immunology, Department of Biotechnology and Biomedicine, Technical University of Denmark, Lyngby, Denmark.

3) Bacterial Infections, Dept of Microbiology and Infection Control, Statens Serum Institut

This article has been accepted for publication and undergone full peer review but has not been through the copyediting, typesetting, pagination and proofreading process, which may lead to differences between this version and the Version of Record. Please cite this article as doi: 10.1111/all.13461

This article is protected by copyright. All rights reserved. 


\section{Correspondence:}

Professor Hans Bisgaard, MD, DMSc

COPSAC, Copenhagen Prospective Studies on Asthma in Childhood

University Hospital of Copenhagen, Herlev and Gentofte, Copenhagen, Denmark

E-mail: bisgaard@copsac.com

Website: www.copsac.com

Article type: Original article

Online Repository: Yes

Short title: Neonatal airway colonization and low-grade inflammation

\section{Authors Contributions:}

The guarantor of the study is $\mathrm{HB}$, from conception and design to conduct of the study and acquisition of data, data analysis, and interpretation of data. SB, KK, MK and SS have all been involved in laboratory work and processing of biological data samples. NRF, JT, BC, JS and KB have done all preliminary analysis, all final analysis and interpretation of data have been discussed and reviewed by co-authors SB, KK, MK and SS. All co-authors have provided important intellectual input to the manuscript. NRF has written the first draft of the manuscript. All authors have agreed that the accuracy and integrity of any part of the work has been appropriately investigated and resolved and all have approved the final version of the manuscript. The corresponding author had full access to the data and had final responsibility for the decision to submit for publication. No honorarium, grant, or other form of payment was given to anyone to produce the manuscript.

This article is protected by copyright. All rights reserved. 


\section{Source of Funding:}

COPSAC is funded by private and public research funds all listed on www.copsac.com. The Lundbeck Foundation (Grant no R16-A1694); The Danish Ministry of Health (Grant no 903516); Danish Council for Strategic Research (Grant no 0603-00280B); The Danish Council for Independent Research (Grant no 10-082884 and 271-08-0815) and The Capital Region Research Foundation (No grant number) have provided core support for COPSAC. No pharmaceutical company was involved in the study. The funding agencies did not have any role in design and conduct of the study; collection, management, and interpretation of the data; or preparation, review, or approval of the manuscript.

\section{Conflict of interest:}

Authors declare no potential, perceived, or real conflict of interest regarding the content of this manuscript.

\section{Governance:}

We are aware of and comply with recognized codes of good research practice, including the Danish Code of Conduct for Research Integrity. We comply with national and international rules on the safety and rights of patients and healthy subjects, including Good Clinical Practice (GCP) as defined in the EU's Directive on Good Clinical Practice, the International Conference on Harmonization's (ICH) good clinical practice guidelines and the Helsinki Declaration. We follow national and international rules on the processing of personal data, including the Danish Act on Processing of Personal Data and the practice of the Danish Data Inspectorate.

This article is protected by copyright. All rights reserved. 


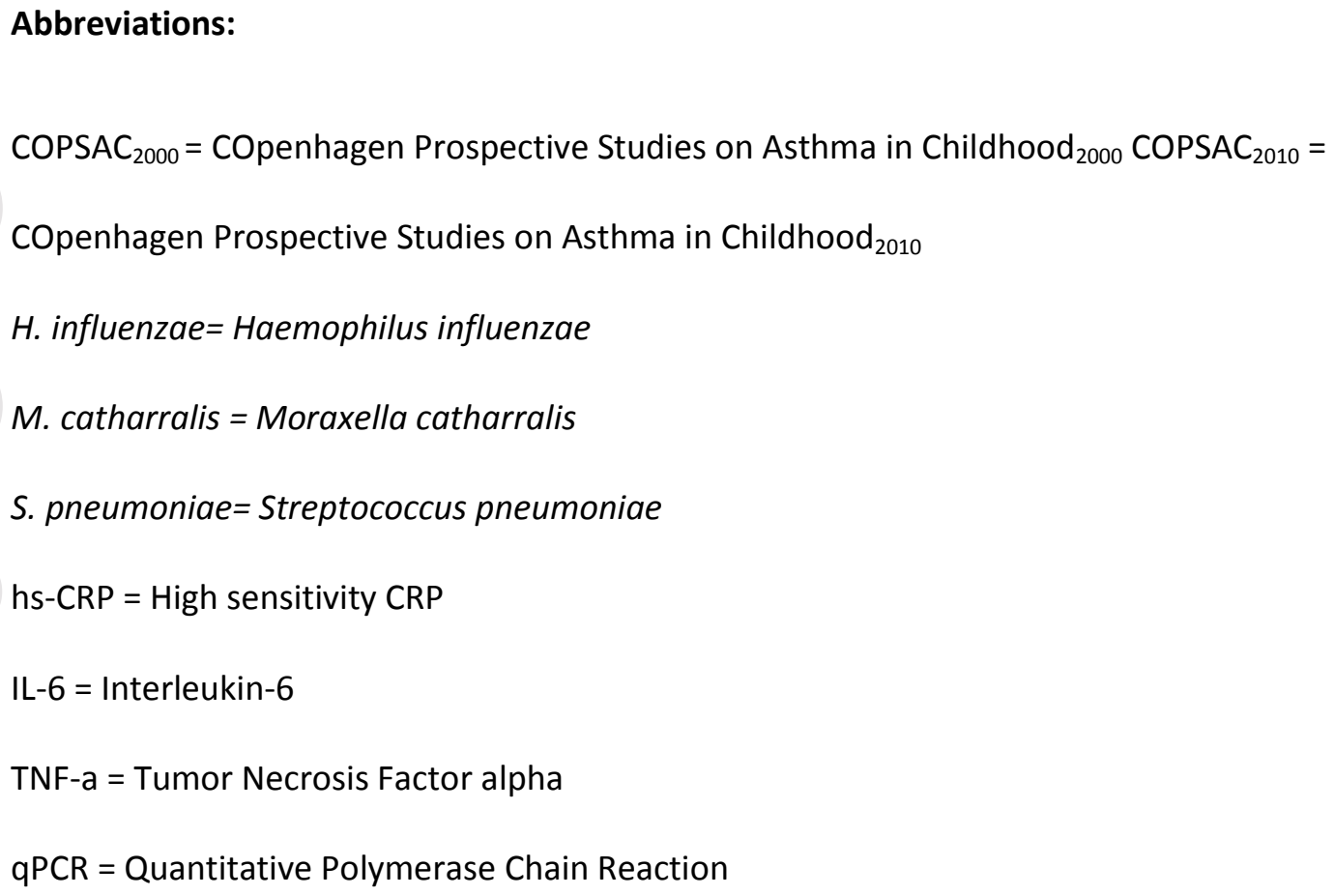

\section{ABSTRACT}

Background and Objectives: The development of childhood asthma is associated with neonatal colonization with pathogenic bacteria in hypopharynx. Furthermore, established asthma is associated with systemic low-grade inflammation. We here report on the association between neonatal colonization with pathogenic bacteria in hypopharynx and the development of systemic low-grade inflammation.

Methods: Bacterial colonization of the hypopharynx with $M$. catharralis, $H$. influenzae and/or S. pneumoniae was assessed in asymptomatic children from the Copenhagen Prospective Studies on Asthma in Childhood ${ }_{2000}\left(\right.$ COPSAC $\left._{2000}\right)$ cohort at age 1 month by culturing technique $(\mathrm{N}=238)$ and by quantitative polymerase chain reaction ( $q P C R)$ technique $(N=249)$ and in the $\operatorname{COPSAC}_{2010}$ cohort by culturing at age 1 month $(\mathrm{N}=622)$ and again at age 3 months $(\mathrm{N}=613)$. Systemic low-

This article is protected by copyright. All rights reserved. 
grade inflammation was determined in both cohorts at age 6 months by measuring plasma levels of high-sensitivity C-reactive protein (hs-CRP), tumor necrosis factor- $\alpha$ (TNF- $\alpha$ ) and interleukine-6 (IL-6).

Results: In both cohorts, bacterial colonization was associated with increased levels of hs-CRP: COPSAC $_{2000}, 1$ month culturing (geometric mean ratio of colonized/non-colonized [95\% Cl]), 1.39 [0.97-2.01], $p=0.08,1$ month qPCR, 1.55 [1.14-2.10], $p<0.01 ;$ COPSAC $_{2010}, 1$ month, 1.52 [1.231.87], $p<0.01$, and 3 month, 1.57 [1.30-1.90], $p<0.01$. A multi-parametric principal component analysis incorporating hs-CRP, TNF- $\alpha$ and IL- 6 confirmed a systemic inflammatory profile in children colonized with M. catharralis, H. influenzae and/or S. pneumoniae in the hypopharynx compared to non-colonized children ( $p$-values<0.05).

Conclusion: The composition of the upper airway microbiome in early life may cause systemic low-grade inflammation.

Keywords: asthma, clinical immunology, environment and hygiene hypothesis, innate immunity, pediatrics.

\section{INTRODUCTION}

Chronic inflammatory diseases such as asthma (1), allergy (2), chronic obstructive pulmonary disease (3), cardiovascular disease (4), obesity (5), and diabetes mellitus (6) have been reported to be associated with a low-grade systemic inflammation as reflected in elevated biomarkers such as high-sensitivity C-reactive protein (hs-CRP). This suggests a shared disease mechanism in chronic inflammatory disorders, which is proposed to be caused by alterations of the gut microbiome (7-9), and possibly the airway microbiome (10-12).

This article is protected by copyright. All rights reserved. 
The airway microbiome of the hypopharynx in neonates has been associated with the development of childhood asthma $(13,14)$. The airway microbiome is believed to play a key role regulating chronic airway inflammation $(10,12)$, but it is unknown whether the early life airway microbiome is also associated with systemic low-grade inflammation.

The aim of this study was to analyze systemic inflammation in neonates colonized in the upper airways with $M$. catharralis, $H$. influenzae and/or S. pneumonia. The analyses were performed in children in the at-risk mother-child cohort Copenhagen Prospective Studies on Asthma in Childhood, COPSAC 2000 , and replication was sought in the unselected COPSAC $_{2010}$ mother-child cohort.

\section{METHODS}

\section{Study Populations}

Data was obtained from the two ongoing clinical mother-child cohorts, COPSAC 2000 and COPSAC $_{2010}$, both from Zealand, Denmark. COPSAC 2000 is a high-risk cohort including 411 children of asthmatic mothers, where exclusion criteria were any congenital abnormality, a gestational age below 36 weeks, and any respiratory symptoms before the inclusion visit at age one month (15). COPSAC 2010 is a population-based cohort enrolling 738 pregnant women from 24 weeks of gestation and their 700 children. Exclusion criteria were women with any endocrine, heart, or kidney disorder or a vitamin D intake above $600 \mathrm{IU} / \mathrm{d}$ (16).

The Local Ethics Committee (COPSAC 2000 : KF 01-289/96, COPSAC 2010 : H-B-2008-093) and the Danish Data Protection Agency (COPSAC 2000 and COPSAC 2010 : 2015-41-3696) approved the studies. Both parents gave oral and written informed consent before enrolment.

This article is protected by copyright. All rights reserved. 


\section{Assessments of Bacterial Colonization of the Hypopharynx}

COPSAC $_{2000}$ : At the age of one month, an airway aspirate was sampled in asymptomatic neonates with a soft suction catheter passed through the nose into the hypopharynx (13-15). At the same visit, swaps were obtained from the nasopharynx by sterile ESwab (Copan Diagnostic Inc., CA USA) through the nasal cavity.

COPSAC $_{2010}$ : Airway aspirates were collected at age one month and again at age three months from the hypopharynx using the same standard operating procedure as in COPSAC $_{2000}$ described above.

Microbial identification of $M$. catarrhalis, $H$. influenzae and S. pneumoniae was performed by culturing using standard methods using with non-selective and selective media, combined with characteristics of colonies, and cellular morphology $(13,17,18)$. All bacterial identifications were confirmed biochemically by automated identification system VITEK 2 (Bio Mérieux, France).

Swaps were analyzed by quantitative polymerase chain reaction (qPCR) for presence of $M$. catarrhalis, H. influenzae and/or S. pneumoniae, by targeting specific genes with primers (see Online Supplement for details). In brief, qPCR assay results were analysed in Applied BioSystem 7500 Software v2.0.6 (Life Technologies, Waltham, MA, USA) and considered positive at a threshold value of 0.2 genome equivalents per microliter (geq/ $\mu \mathrm{L})$ template DNA.

\section{Assessment of Systemic Inflammation}

Systemic inflammation was assessed at age 6 months in both cohorts by measuring plasma levels of blood inflammatory markers: hs-CRP, tumor necrosis factor- $\alpha$ (TNF- $\alpha$ ) and interleukin-6 (IL-6). These biomarkers were chosen a priori as they are established measures of systemic inflammation $(19,2)$. Blood was drawn from a cubital vein into an EDTA tube, centrifuged to

This article is protected by copyright. All rights reserved. 
separate plasma and cells, and immediately stored at $-80^{\circ} \mathrm{C}$ until analysis. After thawing, biomarker levels were determined by a high sensitivity ELISA technique based on electrochemiluminescence. Samples were read in duplicate by using the Sector Image 2400A (Meso Scale Discovery, Gaitherburg, MD). Lower limit of detection (LLOD) was $0.007 \mathrm{ng} / \mathrm{mL}$ for hs-CRP, $0.093 \mathrm{pg} / \mathrm{mL}$ for TNF- $\alpha$ and $0.178 \mathrm{pg} / \mathrm{mL}$ for IL-6.

\section{Covariates}

Infections: Evaluation of infections was based on doctor diagnosis and symptoms documented in diaries. Symptoms monitored included upper and lower respiratory tract infections, gastroenteritis and fever with unknown cause. Current infection was defined as any such infection in a period of two weeks prior to blood sampling $(14,15,20)$.

Siblings included biologically or non-biologically related children, living at the child's address during the child's first year of life.

\section{Statistical Analysis}

Levels of hs-CRP, TNF- $\alpha$ and IL- 6 were log-transformed prior to analysis and reported as median levels (interquartile range, IQR) (see online Table E1 for details). Before log-transformation, the lower limit of detection was added to all measurements as a pseudo-count to avoid zero values.

Upper airway colonization with M. catarrhalis, H. influenzae and/or S. pneumoniae was analyzed as a dichotomous variable (colonized vs. non-colonized). Associations between bacterial colonization and inflammatory markers were examined separately in each cohort using general linear models for analyses adjusted for siblings $(13,17)$ and current infections $(21)$. All results are reported as adjusted geometric mean ratio (GMR) of colonized/non-colonized with $95 \%$

This article is protected by copyright. All rights reserved. 
confidence interval $[\mathrm{Cl}]$. Wilcoxon rank sum test was used for skewed data. In addition, we did a combined analysis of the bacterial culturing results from age one month in both cohorts with an inverse variance meta-analysis using the R-package "meta" (22).

We also conducted a supplementary multi-parametric principal component analysis (PCA) in both cohort studies, including all biomarker levels of hs-CRP, IL- 6 and TNF- $\alpha$, and analyzed the relationship between bacterial colonization of the hypopharynx and principal component 1 (PC1).

All analyses were done with SAS, version 9.4 (SAS institute, Cary, NC) or R version 3.2.3 (The R Foundation for Statistical Computing) (23) and visualized with the "ggplot2" package (24). Further details are given in the online repository.

\section{RESULTS}

\section{Baseline Characteristics}

In COPSAC $_{2000}, 238(58 \%)$ of the 411 children had data both on inflammatory biomarker levels and on bacterial colonization of hypopharynx determined by culturing technique, and 248 (60\%) had data both on inflammatory biomarker levels and on bacterial colonization determined by qPCR technique.

In COPSAC $_{2010}, 622$ (89\%) of the 700 children had data both on inflammatory biomarker levels and bacterial colonization at age 1 month, and $613(88 \%)$ had data both on inflammatory biomarker levels and airway colonization at age 3 months (online Figure E1).

This article is protected by copyright. All rights reserved. 
Infection in the 2-weeks before the time of blood sampling for assessment of inflammatory biomarker levels was reported for $122(30 \%)$ of the included children in COPSAC 2000 and $174(31 \%)$ of the children in COPSAC $_{2010}$. Children with infection vs. without infection in the 2-weeks before blood sampling had increased levels of hs-CRP, median (IQR): COPSAC $2000,0.43 \mathrm{mg} / \mathrm{L}$ [0.17-0.53] vs. $0.09 \mathrm{mg} / \mathrm{L}[0.04-0.32], \mathrm{p}<0.01$, and $\operatorname{COPSAC}_{2010}, 0.04 \mathrm{mg} / \mathrm{L}[0.08-0.57]$ vs. $0.09 \mathrm{mg} / \mathrm{L}[0.05-$ $0.27], p<0.01$.

Baseline characteristics of included and excluded children from the two cohorts are described in Table 1, showing no significant differences between included and excluded children in the COPSAC $_{2000}$ cohort. In the COPSAC 2010 cohort, the included vs. excluded children were less often exposed to smoking during pregnancy $(42(7 \%)$ vs. $12(15 \%), p=0.01)$ and had a higher gestational age (mean 279 days (SD, 11) vs. 276 (16), $\mathrm{p}=0.01$ ).

\section{Bacterial Colonization and Systemic Low-grade Inflammation}

COPSAC $_{2000}$ : M. catarrhalis, $H$. influenzae and/or S. pneumoniae was detected in $52(22 \%)$ of the 238 cultured samples and in 86 (35\%) of the 248 samples analyzed by qPCR. A total of 222 children had samples analyzed by both qPCR and conventional culturing technique; 87 (39\%) were positive by either method, $39(17 \%)$ by both methods, whereas $38(17 \%)$ were positive only by qPCR contrasting $10(5 \%)$ only by culturing technique.

Children who were colonized at age 1 month determined by culturing had a median [IQR] hs-CRP level at age 6 months of $0.30 \mathrm{mg} / \mathrm{L}$ [0.08-0.51] compared to $0.13 \mathrm{mg} / \mathrm{L}$ [0.05-0.47] for noncolonized children: GMR of colonized/non-colonized [95\% Cl], 1.4 [0.9-2.0], p=0.08.

Level of hs-CRP was significantly elevated among children who were colonized at age 1 month determined by qPCR; median [IQR] hs-CRP level was $0.23 \mathrm{mg} / \mathrm{L}[0.08-0.50]$ for colonized children

This article is protected by copyright. All rights reserved. 
compared to $0.11 \mathrm{mg} / \mathrm{L}$ [0.04-0.38] for non-colonized children: GMR, 1.55 [1.1-2.1], $p<0.01$.

Adjusting these analyses for infections and siblings resulted in similar results though with slightly lower estimates, particularly after adjustment for older siblings (Table 2).

COPSAC $_{2010}:$ M. catarrhalis, H. influenzae and/or S. pneumoniae was detected by culturing in 182 (29\%) of 622 children at age 1 month and in 264 (43\%) of 613 children at age 3 months. A total of $319(53 \%)$ children were colonized at one or both time points of whom 106/319 (33\%) were colonized at both time points, 64/319 (20\%) were only colonized at age 1 month, and 149/319 (47\%) were only colonized at age 3 months (online Table E2). Colonization at age 1 month was associated with increased hs-CRP,colonized vs. non-colonized, $0.23 \mathrm{mg} / \mathrm{L}$ [0.07-0.53] vs. 0.10 $\mathrm{mg} / \mathrm{L}$ [0.05-0.38], GMR, 1.52 [1.2-1.9], $\mathrm{p}<0.01$, with similar findings for colonization at age 3 months, $0.22 \mathrm{mg} / \mathrm{L}$ [0.07-0.52] vs. $0.09 \mathrm{mg} / \mathrm{L}$ [0.05-0.37]; GMR, 1.57 [1.30-1.90], $p<0.01$ (Figure 1). Analyses adjusted for infections and siblings yielded similar results (Table 2).

A sensitivity analysis excluding all samples from children with infections in the 2-weeks before the time of blood sampling for assessment of inflammatory biomarker levels showed a similar association between bacterial colonization and elevated levels of hs-CRP in both cohorts (Table 3).

Analyzing the hs-CRP data with non-parametric statistical tests yielded similar results (online Table E3).

Adjusting the association between colonization at age 1 month and hs-CRP for colonization at age 3 month and vice versa, still revealed significant associations from colonization at both time points, showing independent contribution to systemic low-grade inflammation from each time point.

This article is protected by copyright. All rights reserved. 
A combined analysis of the age 1 month conventional culturing results from $\operatorname{COPSAC}_{2000}$ and COPSAC $_{2010}$ showed that bacterial colonization was associated with elevated hs-CRP levels: GMR 1.49, $\mathrm{Cl}[1.3-1.8], \mathrm{p}<0.01$ (Table 2 and Figure 2).

TNF- $\alpha$ and IL- 6 blood levels showed similar results as hs-CRP, with increased levels in colonized vs. non-colonized children, but the associations were less significant (see online Figure E2).

Analyzing the pathogen-specific associations between colonization with M. catarrhalis, $H$. influenzae or S. pneumoniae and hs-CRP levels showed similar trends of elevated hs-CRP, but less pronounced as the signal from colonization with either of the pathogens, which is presumably due to lower power in these subgroup analysis (online Table E4). Table E5 shows pathogenspecific associations with IL-6 and TNF- $\alpha$ level.

\section{Multi-parametric PCA}

The multi-parametric PCA approach is a data-driven way to reduce the variance across the three different cytokines captured in PC-1, which is a proxy of the overall inflammatory response.

COPSAC $_{2000:}$ PC-1 from the multi-parametric PCA incorporating hs-CRP, IL-6 and TNF- $\alpha$ (Figure 3), explained $55 \%$ of the total variance in the biomarker data set. All three markers were positively correlated in PC-1, and especially IL-6 and hs-CRP were highly correlated. Bacterial colonization of hypopharynx determined by culturing at age 1 month was significantly associated with PC-1:

GMR, 1.4 [1.0-1.9], $p=0.04$, with a similar association for qPCR results: GMR, 1.5 [1.2-1.9], $p<0.01$.

This article is protected by copyright. All rights reserved. 
COPSAC $_{2010}$ : PC-1 from the PCA on the COPSAC 2010 dataset also explained $55 \%$ of the variance. Colonization at age 1 month and 3 months were both significantly associated with the inflammatory profile represented by PC-1: GMR, 1.4 [1.2-1.7], $p<0.01)$ and 1.5 [1.2-1.7], $p<0.01$, respectively (Table 4).

PC-1 was stronger and more significantly associated with airway colonization than analyzing the cytokines separately with traditional univariate statistical approaches (online table E5 and Figure 3).

\section{DISCUSSION}

\section{Primary Findings}

Asymptomatic neonates colonized with M. catarrhalis, H. influenzae and/or S. pneumoniae in the upper airways have systemic low-grade inflammation. This was shown in a mother-child cohort at-risk of asthma and subsequently replicated in an unselected mother-child cohort, where asymptomatic bacterial colonization of hypopharynx at both 1 and 3 months was associated with increased hs-CRP levels, suggesting that a perturbed upper airway microbiome may cause a systemic low-grade inflammation.

\section{Strengths and Limitations}

A major advantage of the study is the unique data on bacterial upper airway colonization in asymptomatic neonates and assessment of blood inflammatory markers in infancy measured at similar age points in two independent birth cohorts. While COPSAC ${ }_{2000}$ is a high-risk birth cohort of children born to mothers with asthma, COPSAC 2010 is a population-based cohort. The similar findings in these two cohorts confirm that the association between neonatal bacterial airway

This article is protected by copyright. All rights reserved. 
colonization and a systemic low-grade inflammatory process is a true relation. The association in COPSAC $_{2010}$ between colonization at age 3 months and systemic low-grade inflammation further supports a link between the upper airway microbiome and systemic inflammation.

Both conventional culturing and $\mathrm{qPCR}$ techniques were applied in $\mathrm{COPSAC}_{2000}$ at age 1 month, whereas colonization data from $\operatorname{COPSAC}_{2010}$ at both age 1 month and 3 months were obtained by culturing, which is less sensitive than qPCR. This was illustrated by a stronger association between qPCR data and hs-CRP vs. culturing data and hs-CRP in COPSAC 2000 , whilst the culturing results from both age 1 month and 3 months in COPSAC 2010 were strongly associated with elevated hsCRP, probably because of the higher numbers.

The panel of bacteria assessed in this study only represents a small fraction of the complex biological composition of the diverse airway ecosystem of bacteria, fungi and viruses $(25,26)$. We restricted the study to the three most common pathogenic airway bacteria (M. catarrhalis, $H$. influenzae and/or S. pneumoniae) because we previously demonstrated that colonization with either of these bacteria in the hypopharyngeal region was associated with development of childhood asthma (13). We assume that these bacteria originate from the lower airways, but the possibility of contamination from the oral/upper gastroentestinal microbiome cannot be ruled out.

The measurement of inflammatory biomarkers was done three to five months after assessment of bacterial colonization, which can be seen as both strength and a limitation. Simultaneous assessments of microbes and systemic low-grade inflammation would have allowed a more direct evaluation of this relationship and ruled out that other factors led to or contributed to increased biomarker levels. Conversely, this temporal asynchronicity may suggest a more permanent inflammatory phenotype in the colonized children.

This article is protected by copyright. All rights reserved. 
Detailed information from daily diary cards of common infections in early childhood allowed us to robustly adjust the analyses for infections in a 2-week time period before measurement of blood inflammatory biomarker levels, which did not alter the findings. The frequency of infections was high, but similar in the two independent cohorts, and was associated with increased levels of hsCRP.

Adjusting the analyses for siblings, which in our date was associated with both bacterial colonization (13) and hs-CRP levels (19), resulted in slightly smaller effect sizes and loss of significance in some of the analyses, but did not affect the overall conclusions. This is interesting given the fact that siblings has been shown to decrease the risk of developing allergic rhinitis (27), which we have shown is associated with elevated hs-CRP levels at school-age (2). We speculate that the observation of association between siblings and hs-CRP levels in our study is driven by a relationship between siblings, an altered microbial exposure, and susceptibility to develop infections in early life.

\section{Interpretation}

Asymptomatic bacterial colonization in hypopharynx with M. catarrhalis, H. influenzae and/or S. pneumoniae at age one month and at age three months was independently associated with a systemic low-grade inflammation at six months of age. This may reflect an intermediary process between a perturbed upper airway microbiome and development of childhood asthma as systemic low-grade inflammation has previously been associated with asthma and decreased lung function in asthmatics (28).

Emerging evidence indicates that altered microbial colonization patterns are involved in the physiologic, immunologic, and metabolic deregulation seen in asthma and other chronic inflammatory diseases $(7,31-34)$. Most studies have focused on the role of the gut microbiome in

This article is protected by copyright. All rights reserved. 
subjects with ongoing chronic inflammatory diseases, whereas few studies have investigated the airway microbiome and systemic inflammation in chronic inflammatory diseases $(33,34)$, and no studies have investigated the relationship between the early life airway microbiome and systemic inflammation before disease development.

We have previously demonstrated $(13,35)$ and replicated $(14)$ that asymptomatic bacterial colonization in hypopharynx at age one month was associated with the risk of recurrent wheeze, childhood asthma and lower respiratory tract infections. We also reported that polymorph blood mononuclear cells from children later developing asthma showed an exaggerated ex vivo response to the same airway bacteria at 6 months of age, i.e. before disease development $(36,37)$. Further, we showed that bacterial colonization in hypopharynx was associated with a local up-regulation of pro-inflammatory immune mediators in the upper airways (17). The current study shows that colonization of the upper airways is also associated with a systemic low-grade inflammation.

Despite the observational nature of the study it appears most likely that the causal direction is the airway microbiome causing a systemic low-grade inflammation, rather than the other way around. Thus, the specific composition of the upper airway microbiome characterized by presence of $M$. catarrhalis, $H$. influenzae and/or S. pneumoniae in hypopharynx may be speculated to induce an inflammatory airway response leading to a prolonged systemic low-grade inflammation and a trajectory towards childhood asthma. However, we cannot rule out that the indications of a local as well as a systemic inflammation is a reflection of a pre-existing aberrant immune system allowing pathogenic bacteria to establish themselves in the airways.

\section{Conclusion}

Pathogenic bacterial colonization of the upper airways in asymptomatic infants is associated with a systemic low-grade inflammation. This may reflect an intermediary process between a perturbed upper airway microbiome and development of childhood asthma.

This article is protected by copyright. All rights reserved. 


\section{ACKNOWLEDGEMENTS}

We express our deepest gratitude to the children and families of the COPSAC 2000 and 2010 cohort studies for all their support and commitment. We acknowledge and appreciate the unique efforts of the COPSAC research team, technician Lisbeth Buus Rosholm at DTU Bioengineering, Denmark for inflammatory biomarker analysis and Jørgen Skov Jensen, Consultant physican, MD, PhD, DMSc, Dep. of Microbiology \& Infection Control, Statens Serum Institut.

\section{REFERENCES}

1. Navratil M, Plavec D, Dodig S, Jelcic Z, Nogalo B, Erceg D, et al. Markers of systemic and lung inflammation in childhood asthma. J Asthma Off J Assoc Care Asthma. 2009 Oct;46(8):8228.

2. Chawes BL, Stokholm J, Schoos A-MM, Fink NR, Brix S, Bisgaard H. Allergic sensitization at school age is a systemic low-grade inflammatory disorder. Allergy. 2016 Dec 19;

3. Thomsen $M$, Ingebrigtsen TS, Marott JL, Dahl M, Lange P, Vestbo J, et al. Inflammatory biomarkers and exacerbations in chronic obstructive pulmonary disease. JAMA J Am Med Assoc. 2013 Jun 12;309(22):2353-61.

4. Sabatine MS, Morrow DA, Jablonski KA, Rice MM, Warnica JW, Domanski MJ, et al. Prognostic significance of the Centers for Disease Control/American Heart Association highsensitivity C-reactive protein cut points for cardiovascular and other outcomes in patients with stable coronary artery disease. Circulation. 2007 Mar 27;115(12):1528-36.

5. Nappo A, lacoviello L, Fraterman A, Gonzalez-Gil EM, Hadjigeorgiou C, Marild S, et al. Highsensitivity C-reactive protein is a predictive factor of adiposity in children: results of the identification and prevention of dietary- and lifestyle-induced health effects in children and infants (IDEFICS) study. J Am Heart Assoc. 2013 Jun 6;2(3):e000101.

6. Hung M-J, Hsu K-H, Hu W-S, Chang N-C, Hung M-Y. C-reactive protein for predicting prognosis and its gender-specific associations with diabetes mellitus and hypertension in the development of coronary artery spasm. PloS One. 2013;8(10):e77655.

7. West $\mathrm{CE}$, Renz H, Jenmalm MC, Kozyrskyj AL, Allen KJ, Vuillermin P, et al. The gut microbiota and inflammatory noncommunicable diseases: Associations and potentials for gut microbiota therapies. J Allergy Clin Immunol. 2015 Jan;135(1):3-13.

This article is protected by copyright. All rights reserved. 
8. Azad MB, Konya T, Maughan H, Guttman DS, Field CJ, Sears MR, et al. Infant gut microbiota and the hygiene hypothesis of allergic disease: impact of household pets and siblings on microbiota composition and diversity. Allergy Asthma Clin Immunol. 2013 Apr 22;9(1):15.

9. Cerf-Bensussan N, Gaboriau-Routhiau V. The immune system and the gut microbiota: friends or foes? Nat Rev Immunol. 2010 Oct;10(10):735-44.

10. Marsland BJ. Regulation of inflammatory responses by the commensal microbiota. Thorax. 2012 Jan;67(1):93-4.

11. Marsland BJ, Trompette A, Gollwitzer ES. The Gut-Lung Axis in Respiratory Disease. Ann Am Thorac Soc. 2015 Nov;12 Suppl 2:S150-156.

12. Salami O, Marsland BJ. Has the airway microbiome been overlooked in respiratory disease? Genome Med. 2015;7(1):62.

13. Bisgaard H, Hermansen MN, Buchvald F, Loland L, Halkjaer LB, Bønnelykke K, et al. Childhood asthma after bacterial colonization of the airway in neonates. N Engl J Med. 2007 Oct 11;357(15):1487-95.

14. von Linstow M-L, Schønning K, Hoegh AM, Sevelsted A, Vissing NH, Bisgaard H. Neonatal airway colonization is associated with troublesome lung symptoms in infants. Am J Respir Crit Care Med. 2013 Oct 15;188(8):1041-2.

15. Bisgaard H. The Copenhagen Prospective Study on Asthma in Childhood (COPSAC): design, rationale, and baseline data from a longitudinal birth cohort study. Ann Allergy Asthma Immunol Off Publ Am Coll Allergy Asthma Immunol. 2004 Oct;93(4):381-9.

16. Bisgaard H, Vissing NH, Carson CG, Bischoff AL, Følsgaard NV, Kreiner-Møller E, et al. Deep phenotyping of the unselected COPSAC2010 birth cohort study. Clin Exp Allergy J Br Soc Allergy Clin Immunol. 2013 Dec;43(12):1384-94.

17. Følsgaard NV, Schjørring S, Chawes BL, Rasmussen MA, Krogfelt KA, Brix S, et al. Pathogenic bacteria colonizing the airways in asymptomatic neonates stimulates topical inflammatory mediator release. Am J Respir Crit Care Med. 2013 Mar 15;187(6):589-95.

18. Bisgaard H, Hermansen MN, Bønnelykke K, Stokholm J, Baty F, Skytt NL, et al. Association of bacteria and viruses with wheezy episodes in young children: prospective birth cohort study. BMJ. 2010;341:c4978.

19. Chawes BL, Stokholm J, Bønnelykke K, Brix S, Bisgaard H. Neonates with reduced neonatal lung function have systemic low-grade inflammation. J Allergy Clin Immunol. 2015;

20. Bisgaard H, Pipper CB, Bønnelykke K. Endotyping early childhood asthma by quantitative symptom assessment. J Allergy Clin Immunol. 2011 May;127(5):1155-1164.e2.

21. Chawes BLK. Upper and lower airway pathology in young children with allergic- and nonallergic rhinitis. Dan Med Bull. 2011 May;58(5):B4278.

This article is protected by copyright. All rights reserved. 
22. Schwarzer G. meta: An R package for meta-analysis. R News. 2007;7(3):40-45.

23. R Core Team. R: A Language and Environment for Statistical Computing [Internet]. Vienna, Austria: R Foundation for Statistical Computing; 2015. Available from: http://www.Rproject.org/

24. Wickham H. ggplot2: Elegant Graphics for Data Analysis [Internet]. Springer-Verlag New York; 2009. Available from: http://had.co.nz/ggplot2/book

25. Huffnagle GB, Dickson RP, Lukacs NW. The respiratory tract microbiome and lung inflammation: a two-way street. Mucosal Immunol. 2016 Dec 14;

26. Beigelman A, Bacharier LB. Early-life respiratory infections and asthma development: role in disease pathogenesis and potential targets for disease prevention. Curr Opin Allergy Clin Immunol. 2016 Apr;16(2):172-8.

27. Strachan DP. Hay fever, hygiene, and household size. Br Med J. 1989 Nov 18;299(6710):1259-60.

28. Kony S, Zureik M, Driss F, Neukirch C, Leynaert B, Neukirch F. Association of bronchial hyperresponsiveness and lung function with $\mathrm{C}$-reactive protein (CRP): a population based study. Thorax. 2004 Oct;59(10):892-6.

29. Calderón EJ, Rivero L, Respaldiza N, Morilla R, Montes-Cano MA, Friaza V, et al. Systemic inflammation in patients with chronic obstructive pulmonary disease who are colonized with Pneumocystis jiroveci. Clin Infect Dis Off Publ Infect Dis Soc Am. 2007 Jul 15;45(2):e1719.

30. Ergan Arsava B, Cöplü L. Does airway colonization cause systemic inflammation in bronchiectasis? Tuberk Ve Toraks. 2011;59(4):340-7.

31. Marsland BJ, Yadava K, Nicod LP. The airway microbiome and disease. CHEST J. 2013 Aug 1;144(2):632-7.

32. Singanayagam A, Ritchie Al, Johnston SL. Role of microbiome in the pathophysiology and disease course of asthma. Curr Opin Pulm Med. 2017 Jan;23(1):41-7.

33. Huang YJ. The respiratory microbiome and innate immunity in asthma. Curr Opin Pulm Med. 2015 Jan;21(1):27-32.

34. Burgess SL, Lu M, Ma JZ, Naylor C, Donowitz JR, Kirkpatrick BD, et al. Inflammatory markers predict episodes of wheezing during the first year of life in Bangladesh. Respir Med. 2016 Jan;110:53-7.

35. Vissing NH, Chawes BLK, Bisgaard H. Increased Risk of Pneumonia and Bronchiolitis after Bacterial Colonization of the Airways as Neonates. Am J Respir Crit Care Med. 2013 Nov 15;188(10):1246-52.

This article is protected by copyright. All rights reserved. 
36. Larsen JM, Brix S, Thysen AH, Birch S, Rasmussen MA, Bisgaard H. Children with asthma by school age display aberrant immune responses to pathogenic airway bacteria as infants. J Allergy Clin Immunol. 2014 Mar 4;

37. Vissing NH, Larsen JM, Rasmussen MA, Chawes BLK, Thysen AH, Bønnelykke K, et al. Susceptibility to Lower Respiratory Infections in Childhood is Associated with Perturbation of the Cytokine Response to Pathogenic Airway Bacteria. Pediatr Infect Dis J. 2016 May;35(5):561-6.

This article is protected by copyright. All rights reserved. 
TABELS

Table 1. Baseline characteristics and comparison of included vs. excluded children from the COPSAC $_{2000}$ and COPSAC 2010 birth cohorts.

\begin{tabular}{|c|c|c|c|c|}
\hline & All children & Included children & Excluded children & $\mathbf{p}$ \\
\hline COPSAC $_{2000}$ cohort & 411 & 248 & 163 & \\
\hline $\begin{array}{l}\text { Infection at time of blood } \\
\text { sampling (\%) }\end{array}$ & $122(29.7)$ & $78(32.8)$ & $44(25.4)$ & 0.13 \\
\hline Siblings at home (\%) & $160(40.1)$ & $100(40.8)$ & $60(39.0)$ & 0.79 \\
\hline $\begin{array}{l}\text { Smoking during pregnancy } \\
\text { (\%) }\end{array}$ & $99(24.1)$ & $65(26.2)$ & $34(20.9)$ & 0.26 \\
\hline Passive smoke exposure (\%) & $311(83.2)$ & $191(81.3)$ & $120(86.3)$ & 0.26 \\
\hline Cat in home (\%) & $61(15.4)$ & $36(14.9)$ & $25(16.1)$ & 0.85 \\
\hline Dog in home (\%) & 55 (13.9) & $34(14.1)$ & $21(13.5)$ & 0.97 \\
\hline Natural (vaginal) birth (\%) & $324(78.8)$ & $194(78.2)$ & $130(79.8)$ & 0.80 \\
\hline $\begin{array}{l}\text { Breastfed length, days } \\
\text { (median [IQR]) }\end{array}$ & $122[90.0-155.0]$ & $122[91.0-153.5]$ & $122[78.5-155.5]$ & 0.93 \\
\hline $\begin{array}{l}\text { Daycare start age, days (mean } \\
\text { (SD)) }\end{array}$ & $1.10(0.80)$ & $1.11(0.78)$ & $1.07(0.83)$ & 0.63 \\
\hline Sex, Male (\%) & $203(49.4)$ & $130(52.4)$ & $73(44.8)$ & 0.16 \\
\hline Birth weight (mean (SD)) & $3.52(0.52)$ & $3.50(0.51)$ & $3.54(0.53)$ & 0.53 \\
\hline Birth length (mean (SD)) & $52.30(2.31)$ & $52.22(2.28)$ & $52.42(2.37)$ & 0.38 \\
\hline $\begin{array}{l}\text { Head circumference at birth } \\
\text { (mean (SD)) }\end{array}$ & $352.17(16.22)$ & $351.84(16.17)$ & $352.66(16.33)$ & 0.63 \\
\hline \multirow[t]{2}{*}{$\begin{array}{l}\text { Gestational age, days (mean } \\
\text { (SD)) }\end{array}$} & $282.11(10.74)$ & $282.16(10.74)$ & 282.04 (10.77) & 0.92 \\
\hline & All children & Included children & Excluded children & $\mathbf{p}$ \\
\hline COPSAC $_{2010}$ cohort & 700 & 622 & 78 & \\
\hline Infection at time of blood & $174(31.2)$ & 165 (31.6) & $9(25.0)$ & 0.52 \\
\hline
\end{tabular}

This article is protected by copyright. All rights reserved. 


\begin{tabular}{|c|c|c|c|c|}
\hline sampling (\%) & & & & \\
\hline Siblings at home (\%) & 395 (56.4) & $357(57.4)$ & $38(48.7)$ & 0.18 \\
\hline $\begin{array}{l}\text { Daycare start age, days (mean } \\
\text { (SD)) }\end{array}$ & 326.29 (96.89) & 327.30 (93.77) & $318.10(119.54)$ & 0.43 \\
\hline Passive smoke exposure (\%) & $374(54.4)$ & $340(55.2)$ & $34(47.2)$ & 0.25 \\
\hline $\begin{array}{l}\text { Smoking during pregnancy } \\
\text { (\%) }\end{array}$ & $54(7.7)$ & $42(6.8)$ & $12(15.4)$ & 0.01 \\
\hline Natural (vaginal) birth (\%) & $549(78.4)$ & $489(78.6)$ & $60(76.9)$ & 0.84 \\
\hline Cat in home (\%) & 151 (21.9) & 135 (21.9) & $16(22.2)$ & 1.00 \\
\hline Dog in home (\%) & $150(21.8)$ & $134(21.8)$ & $16(22.2)$ & 1.00 \\
\hline Athmatic mother (\%) & $186(26.6)$ & $162(26.0)$ & $24(30.8)$ & 0.45 \\
\hline $\begin{array}{l}\text { Breastfed length, days } \\
\text { (median [IQR]) }\end{array}$ & $122[46.0-150.0]$ & $122[57.7-150.0]$ & $116[20.0-149.0]$ & 0.09 \\
\hline $\begin{array}{l}\text { Gestational age in days (mean } \\
\text { (SD)) }\end{array}$ & $279.00(11.65)$ & 279.40 (10.92) & $275.78(16.05)$ & 0.01 \\
\hline Birth length (mean (SD)) & $51.87(2.54)$ & $51.90(2.44)$ & $51.62(3.25)$ & 0.35 \\
\hline Birth weight (mean (SD)) & $3.54(0.55)$ & $3.54(0.53)$ & $3.50(0.66)$ & 0.56 \\
\hline $\begin{array}{l}\text { Head circumference at birth } \\
\text { (mean (SD)) }\end{array}$ & $35.00(1.71)$ & $34.99(1.71)$ & $35.05(1.71)$ & 0.76 \\
\hline Sex, Male (\%) & $360(51.4)$ & $319(51.3)$ & $41(52.6)$ & 0.93 \\
\hline $\begin{array}{l}\text { Social circumstances, PCA } \\
\text { score (mean (SD)) }\end{array}$ & $0.00(1.00)$ & $0.00(1.00)$ & $0.03(1.03)$ & 0.79 \\
\hline
\end{tabular}

Table 2. Association between early life bacterial airway colonization with $M$. catharralis, $H$. influenzae and/or S. pneumoniae and levels of hs-CRP at age 6 months in COPSAC 2000, COPSAC $_{2010}$ and combined.

This article is protected by copyright. All rights reserved. 


\begin{tabular}{|c|c|c|c|c|c|}
\hline $\begin{array}{l}\text { COPSAC }_{2000} \text { : } \\
\text { age } 1 \text { month }\end{array}$ & $\begin{array}{c}\text { Colonized } \\
\text { (total n) }\end{array}$ & $\begin{array}{c}\text { Colonized, } \\
\text { median [IQR] } \\
\text { mg/L }\end{array}$ & $\begin{array}{c}\text { Non-colonized, } \\
\text { median [IQR] } \\
\text { mg/L }\end{array}$ & $\begin{array}{c}\text { GMR } \\
{[95 \% \mathrm{CI}]}\end{array}$ & $\mathbf{P}$ \\
\hline Culture data & $\begin{array}{c}52 \\
(238)\end{array}$ & $\begin{array}{c}0.30 \\
{[0.08-0.51]}\end{array}$ & $\begin{array}{c}0.13 \\
{[0.05-0.47]}\end{array}$ & $\begin{array}{c}1.39 \\
{[0.97-2.01]}\end{array}$ & 0.08 \\
\hline $\begin{array}{l}\text { Adjusted for current } \\
\text { infections }\end{array}$ & $\begin{array}{c}52 \\
(238)\end{array}$ & - & - & $\begin{array}{c}1.30 \\
{[0.92-1.84]}\end{array}$ & 0.12 \\
\hline Adjusted for siblings & $\begin{array}{c}52 \\
(238)\end{array}$ & - & - & $\begin{array}{c}1.11 \\
{[0.74-1.65]}\end{array}$ & 0.60 \\
\hline qPCR data & $\begin{array}{c}86 \\
(248)\end{array}$ & $\begin{array}{c}0.23 \\
0.08-0.50]\end{array}$ & $\begin{array}{c}0.11 \\
{[0.04-0.38]}\end{array}$ & $\begin{array}{c}1.55 \\
{[1.14-2.10]}\end{array}$ & $<0.01$ \\
\hline $\begin{array}{l}\text { Adjusted for current } \\
\text { infections }\end{array}$ & $\begin{array}{c}86 \\
(248)\end{array}$ & - & - & $\begin{array}{c}1.48 \\
{[1.09-2.00]}\end{array}$ & 0.01 \\
\hline Adjusted for siblings & $\begin{array}{c}86 \\
(248)\end{array}$ & - & - & $\begin{array}{c}1.33 \\
{[0.95-1.87]}\end{array}$ & 0.09 \\
\hline $\begin{array}{l}\text { COPSAC }_{2010} \text { : } \\
\text { age } 1 \text { month }\end{array}$ & $\begin{array}{c}\text { Colonized } \\
\text { (total } n \text { ) }\end{array}$ & $\begin{array}{c}\text { Colonized, } \\
\text { median [IQR] mg/L }\end{array}$ & $\begin{array}{c}\text { Non-colonized, } \\
\text { median [IQR] mg/L }\end{array}$ & $\begin{array}{c}\text { GMR } \\
{[95 \% \mathrm{Cl}]}\end{array}$ & $\mathbf{P}$ \\
\hline Culture data & $182(622)$ & $\begin{array}{c}0.23 \\
{[0.07-0.53]}\end{array}$ & $\begin{array}{c}0.10 \\
{[0.05-0.38]}\end{array}$ & $\begin{array}{c}1.52 \\
{[1.24-1.87]}\end{array}$ & $<0.01$ \\
\hline $\begin{array}{l}\text { Adjusted for current } \\
\text { infections }\end{array}$ & $154(530)$ & - & - & $\begin{array}{c}1.51 \\
{[1.22-1.86]}\end{array}$ & $<0.01$ \\
\hline Adjusted for siblings & $182(622)$ & - & - & $\begin{array}{c}1.28 \\
{[1.04-1.58]}\end{array}$ & 0.02 \\
\hline $\begin{array}{l}\text { COPSAC }_{2010}: \\
\text { age } 3 \text { months }\end{array}$ & $\begin{array}{c}\text { Colonized } \\
\text { (total } \mathrm{n} \text { ) }\end{array}$ & $\begin{array}{c}\text { Colonized, } \\
\text { median [IQR] mg/L }\end{array}$ & $\begin{array}{c}\text { Non-colonized, } \\
\text { median [IQR] mg/L }\end{array}$ & $\begin{array}{c}\text { GMR } \\
{[95 \% \mathrm{Cl}]}\end{array}$ & $\mathbf{P}$ \\
\hline
\end{tabular}

This article is protected by copyright. All rights reserved. 


\begin{tabular}{|c|c|c|c|c|c|}
\hline Culture data & $264(613)$ & $\begin{array}{c}0.22 \\
{[0.07-0.52]}\end{array}$ & $\begin{array}{c}0.09 \\
{[0.05-0.37]}\end{array}$ & $\begin{array}{c}1.57 \\
{[1.30-1.90]}\end{array}$ & $<0.01$ \\
\hline $\begin{array}{l}\text { Adjusted for current } \\
\text { infections }\end{array}$ & $223(522)$ & - & - & $\begin{array}{c}1.56 \\
{[1.29-1.89]}\end{array}$ & $<0.01$ \\
\hline Adjusted for siblings & $264(613)$ & - & - & $\begin{array}{c}1.32 \\
{[1.08-1.61]}\end{array}$ & $<0.01$ \\
\hline $\begin{array}{l}\text { Combined analysis of } \\
\text { COPSAC }_{2000} \text { and } \\
\operatorname{COPSAC}_{2010} \text { : } \\
\text { age } 1 \text { month }\end{array}$ & $\begin{array}{l}\text { Colonized } \\
\text { (total } n \text { ) }\end{array}$ & $\begin{array}{c}\text { Colonized, } \\
\text { median [IQR] mg/L }\end{array}$ & $\begin{array}{c}\text { Non-colonized, } \\
\text { median [IQR] mg/L }\end{array}$ & $\begin{array}{l}\text { GMR } \\
{[95 \% \mathrm{Cl}]}\end{array}$ & $\mathbf{P}$ \\
\hline Culture data & $234(860)$ & - & - & $\begin{array}{c}1.49 \\
{[1.25-1.78]}\end{array}$ & $<0.01$ \\
\hline $\begin{array}{l}\text { Adjusted for current } \\
\text { infections }\end{array}$ & $206(772)$ & - & - & $\begin{array}{c}1.45 \\
{[1.21-1.74]}\end{array}$ & $<0.01$ \\
\hline Adjusted for siblings & $234(860)$ & - & - & $\begin{array}{c}1.24 \\
{[1.03-1.50]}\end{array}$ & 0.02 \\
\hline
\end{tabular}

This article is protected by copyright. All rights reserved. 
Table 3. Association between bacterial airway colonization and levels of hs-CRP in children with no infections before time of blood sampling in COPSAC 2000 and COPSAC $_{2010}$

\begin{tabular}{|c|c|c|c|c|c|}
\hline COPSAC $_{2000}$ & $\begin{array}{l}\text { Colonized } \\
(\text { total } n)\end{array}$ & $\begin{array}{c}\text { Colonized, } \\
\text { median [IQR] } \\
\text { mg/L }\end{array}$ & $\begin{array}{c}\text { Non-colonized, } \\
\text { median [IQR] } \\
\text { mg/L }\end{array}$ & $\begin{array}{c}\text { GMR } \\
{[95 \% \mathrm{CI}]}\end{array}$ & $\mathbf{P}$ \\
\hline $\begin{array}{l}\text { Culture data, age } 1 \\
\text { month }\end{array}$ & $32(128)$ & $\begin{array}{c}0.10 \\
{[0.05-0.48]}\end{array}$ & $\begin{array}{c}0.89 \\
{[0.05-0.48]}\end{array}$ & $\begin{array}{c}1.39 \\
{[0.89-2.18]}\end{array}$ & 0.15 \\
\hline qPCR data, age 1 month & $58(113)$ & $\begin{array}{c}0.14 \\
{[0.05-0.46]}\end{array}$ & $\begin{array}{c}0.80 \\
{[0.03-0.19]}\end{array}$ & $\begin{array}{c}1.60 \\
{[1.12-2.29]}\end{array}$ & 0.01 \\
\hline COPSAC $_{2010}$ & $\begin{array}{l}\text { Colonized } \\
\text { (total } n \text { ) }\end{array}$ & $\begin{array}{c}\text { Colonized, } \\
\text { median [IQR] mg/L }\end{array}$ & $\begin{array}{c}\text { Non-colonized, } \\
\text { median [IQR] mg/L }\end{array}$ & $\begin{array}{l}\text { GMR } \\
{[95 \% \mathrm{Cl}]}\end{array}$ & $\mathbf{P}$ \\
\hline $\begin{array}{l}\text { Culture data, age } 1 \\
\text { month }\end{array}$ & $137(455)$ & $\begin{array}{c}0.14 \\
{[0.06-0.49]}\end{array}$ & $\begin{array}{c}0.08 \\
{[0.04-0.28]}\end{array}$ & $\begin{array}{c}1.50 \\
{[1.18-1.90]}\end{array}$ & $<0.01$ \\
\hline $\begin{array}{l}\text { Culture data, age } 3 \\
\text { months }\end{array}$ & $185(348)$ & $\begin{array}{c}0.14 \\
{[0.06-0.45]}\end{array}$ & $\begin{array}{c}0.08 \\
{[0.04-0.53]}\end{array}$ & $\begin{array}{c}1.50 \\
{[1.20-1.88]}\end{array}$ & $<0.01$ \\
\hline
\end{tabular}

This article is protected by copyright. All rights reserved. 
Table 4. Multi-parametric analysis of the association between bacterial airway colonization and principle component 1 from a principle component analysis of hs-CRP, TNF-a and IL-6, which explains $55.4 \%$ of the variation in the data.

\begin{tabular}{|c|c|c|c|c|}
\hline $\begin{array}{l}\text { COPSAC }_{2000}: \\
\text { age } 1 \text { month }\end{array}$ & $\begin{array}{c}\text { Colonized, } \\
\text { culturing } \\
(\text { total } n)\end{array}$ & Estimate & {$[95 \% \mathrm{CI}]$} & $\mathbf{P}$ \\
\hline Principal component 1 & $\begin{array}{c}52 \\
(238)\end{array}$ & 1.4 & [1.0-1.9] & 0.04 \\
\hline $\begin{array}{l}\text { Adjusted for current } \\
\text { infections }\end{array}$ & $\begin{array}{c}52 \\
(238)\end{array}$ & 1.3 & {$[0.9-1.8]$} & 0.12 \\
\hline \multirow[t]{2}{*}{ Adjusted for siblings } & $\begin{array}{c}52 \\
(238)\end{array}$ & 1.1 & {$[0.7-1.7]$} & 0.60 \\
\hline & $\begin{array}{l}\text { Colonized, qPCR } \\
\text { (total } \mathrm{n} \text { ) }\end{array}$ & Estimate & {$[95 \% \mathrm{Cl}]$} & $\mathbf{P}$ \\
\hline Principal component 1 & $\begin{array}{c}84 \\
(246)\end{array}$ & 1.5 & [1.2-1.9] & $<0.01$ \\
\hline $\begin{array}{l}\text { Adjusted for current } \\
\text { infections }\end{array}$ & $\begin{array}{c}84 \\
(246)\end{array}$ & 1.5 & {$[1.2-2.1]$} & $<0.01$ \\
\hline Adjusted for siblings & $\begin{array}{c}84 \\
(246)\end{array}$ & 1.35 & {$[0.96-1.9]$} & 0.08 \\
\hline $\begin{array}{l}\text { COPSAC }_{2010} \text { : } \\
\text { age } 1 \text { month }\end{array}$ & $\begin{array}{c}\text { Colonized, } \\
\text { culturing } \\
\text { (total } \mathrm{n} \text { ) }\end{array}$ & Estimate & {$[95 \% \mathrm{Cl}]$} & $\mathbf{P}$ \\
\hline Principal component 1 & $182(622)$ & 1.4 & {$[1.2-1.7]$} & $<0.01$ \\
\hline $\begin{array}{l}\text { Adjusted for current } \\
\text { infections }\end{array}$ & $182(622)$ & 1.5 & {$[1.2-1.9]$} & $<0.01$ \\
\hline Adjusted for siblings & $182(622)$ & 1.3 & {$[1.0-1.6]$} & 0.02 \\
\hline $\begin{array}{l}\text { COPSAC }_{2010} \text { : } \\
\text { age } 3 \text { months }\end{array}$ & $\begin{array}{l}\text { Colonized, } \\
\text { culturing }\end{array}$ & Estimate & {$[95 \% \mathrm{Cl}]$} & $\mathbf{P}$ \\
\hline
\end{tabular}

This article is protected by copyright. All rights reserved. 


\begin{tabular}{|l|c|c|c|c|}
\hline & (total n) & & & \\
\hline Principal component 1 & $264(613)$ & 1.5 & {$[1.2-1.7]$} & $<0.01$ \\
\hline $\begin{array}{l}\text { Adjusted for current } \\
\text { infections }\end{array}$ & $224(526)$ & 1.6 & {$[1.3-1.9]$} & $<0.01$ \\
\hline Adjusted for siblings & $264(613)$ & 1.3 & {$[1.1-1.6]$} & $<0.01$ \\
\hline
\end{tabular}

\section{FIGURE LEGENDS}

Figure 1: hs-CRP levels at age 6 months in children with vs. without early life bacterial airway colonization. The horizontal lines depict group median.

Figure 2: Combined analysis of bacterial airway colonization detected by traditional culturing technique in both cohorts at age 1 month and hs-CRP level at age 6 months.

Figure 3: Principal component analysis biplots incorporating hs-CRP, IL- 6 and TNF- $\alpha$ levels at age 6 months in relation to early life bacterial airway colonization in the COPSAC 2000 (panel A) and COPSAC $_{2010}$ (panel B) birth cohorts. Each point in the panel corresponds to a child. Two points closely related indicates children with similar profiles. The ellipses reflect the two-dimensional distribution of the group of children colonized (red) vs. children not colonized (blue) with pathogenic airway bacteria.

This article is protected by copyright. All rights reserved. 


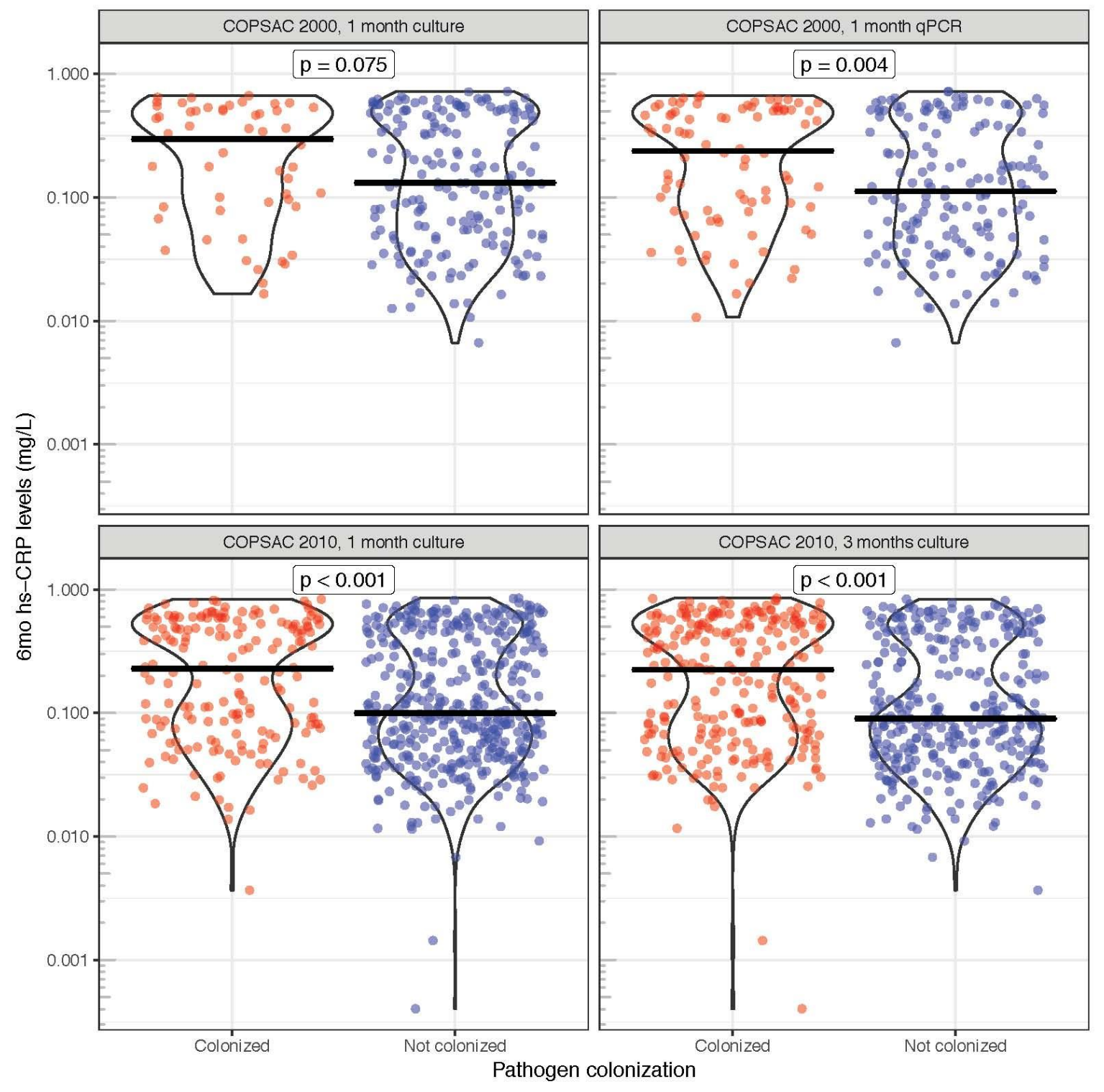

This article is protected by copyright. All rights reserved. 

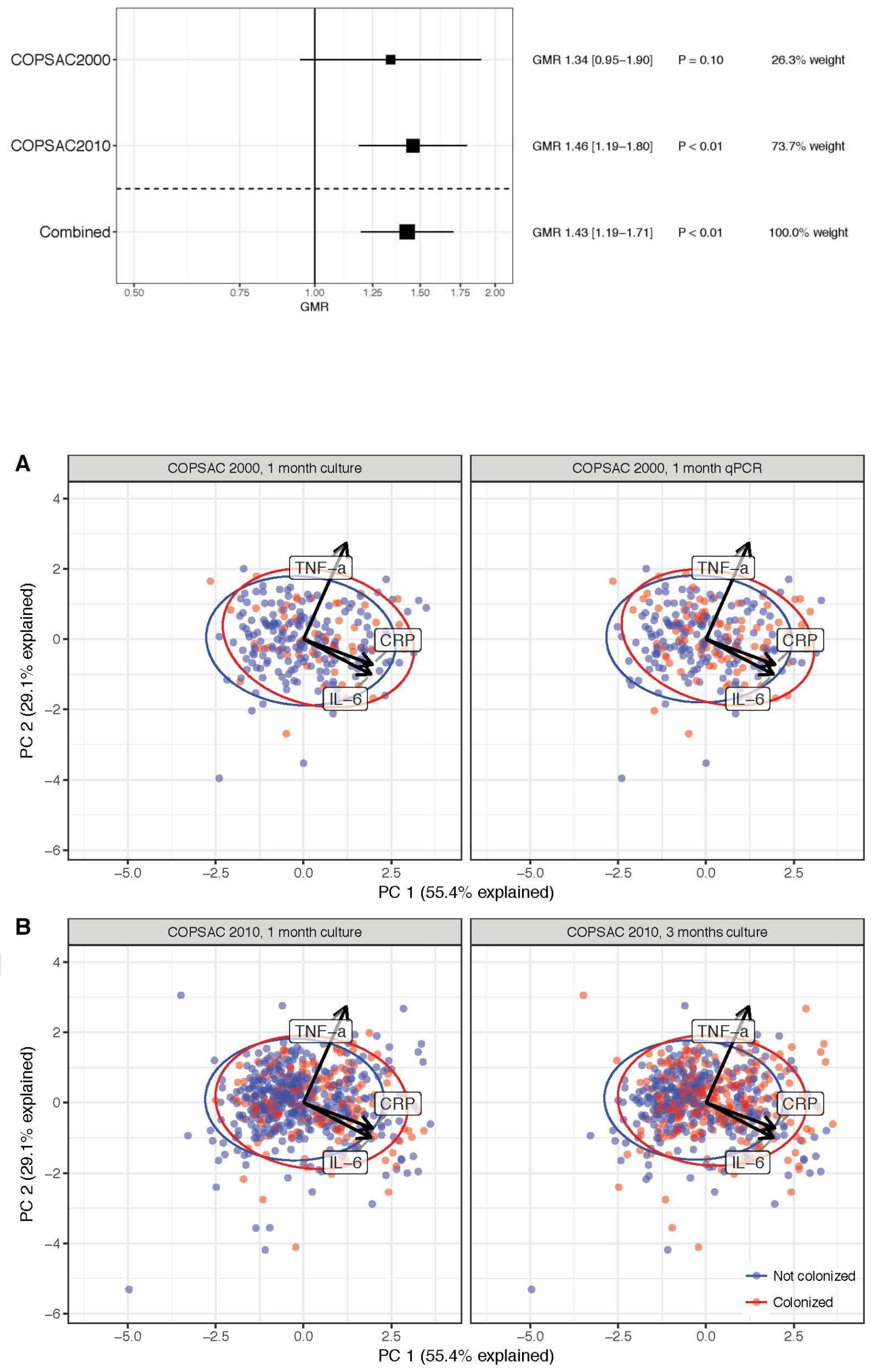

This article is protected by copyright. All rights reserved. 